\title{
BIOACTIVE COMPOUNDS FROM TORBANGUN (Plectranthus amboinicus (LOUr.) SPRENG) CHLOROFORM FRACTION INDUCE APOPTOSIS IN BREAST CANCER (MCF-7 CELLS) IN VITRO
}

\section{SENYAWA BIOAKTIF TORBANGUN (Plectranthus amboinicus (Lour.) SPRENG) FRAKSI KLOROFORM INDUKSI APOPTOSIS PADA KANKER PAYUDARA (SEL MCF-7) IN VITRO}

\author{
Wahid Yulianto1,5, Nuri Andarwulan ${ }^{1,3}{ }^{*}$, Puspo Edi Giriwono ${ }^{1,3}$, Joko Pamungkas, \\ 1Department of Food Science and Technology, Bogor Agricultural University, Bogor, Indonesia \\ 2Department of Animal Disease Science and Veterinary Medicine, Bogor Agricultural University, Bogor, Indonesia \\ ${ }^{3}$ Southeast Asian Food and Agricultural Science and Technology (SEAFAST) Center, Bogor Agricultural University, \\ Bogor, Indonesia \\ 4Primate Research Center, Bogor Agricultural University, Bogor, Indonesia \\ 5Faculty of Animal Husbandry, University of Mataram, Mataram, Indonesia
}

\begin{abstract}
Torbangun (Plectranthus amboinicus (Lour.) Spreng) is a medicinal plant that has been traditionally used in tropical countries to cure various illnesses. The objective of this study was to identify the active compounds in the chloroform fraction which have effect on the apoptosis-related genes expression of breast cancer MCF-7 cells. Apoptosis was observed morphologically using Hoechst nuclear staining. Expression of the genes was analyzed using Real-Time PCR. Chemical compounds of the plant fractions were determined using LC-MS. Result of cell morphology observation clearly indicated apoptosis after the treatment of the plant fraction. Increased expression of anti-apoptotic gene Bcl-2 could not prevent the cells from apoptosis. Expressions of p53 and p21 genes were increased significantly. The expressions of caspase 9, caspase 7 and caspase 1 were increased at concentration-dependent manner. Most of the compounds in the chloroform fraction are identified as diterpenoids which may contribute to the apoptosis inducing activity of the fraction. Key words: Apoptosis mechanism, bioactive compounds; chloroform fraction; gene expression; MCF-7 cells; Torbangun.
\end{abstract}

\section{ABSTRAK}

Tanaman Torbangun (Plectranthus amboinicus (Lour.) Spreng) telah dimanfaatkan secara tradisional pada berbagai negara di daerah tropis untuk menyembuhkan berbagai penyakit. Penelitian ini bertujuan untuk mengidentifikasi komponen aktif pada fraksi kloroform dari ekstrak tanaman torbangun tersebut yang memiliki efek terhadap ekspresi gen-gen yang berkaitan dengan apoptosis pada sel kanker payudara MCF-7. Apoptosis diamati secara morfologis menggunakan metode pewarnaan inti sel Hoechst. Ekspresi gen dianalisa menggunakan Real-Time PCR sedangkan komponen bioaktif diidentifikasi menggunakan LC-MS. Hasil pengamatan morfologi secara jelas memperlihatkan terjadinya apoptosis pada sel setelah diberi perlakuan ekstrak tanaman. Terjadi peningkatan ekspresi gen anti-apoptosis Bcl-2 namun peningkatan tersebut tidak mampu mencegah terjadinya apoptosis pada sel. Ekspresi gen p53 dan p21 meningkat secara signifikan setelah diberi perlakuan fraksi kloroform. Ekspresi gen caspase 9, caspase 7 dan caspase 1 meningkat dengan level peningkatan yang dipengaruhi oleh konsentrasi yang diberikan. Sebagian besar komponen yang teridentifikasi tergolong dalam kelompok diterpenoid yang kemungkinan berkontribusi terhadap bioaktifitas fraksi kloroform dalam menginduksi apoptosis pada sel kanker MCF-7. Kata kunci: Ekspresi gen; fraksi kloroform; komponen bioaktif; mekanisme apoptosis; Torbangun; sel MCF-7

\section{INTRODUCTION}

Apoptosis is a mechanism of genetically programmed autonomous cell death to maintain cell homeostasis. Alterations in the genetics of apoptotic regulatory mechanisms may result in an

Corresponding author : Nuri Andarwulan

Email : andarwulan@apps.ipb.ac.id increase in cell numbers as well as the preservation of genetically abnormal cells which begins the process of tumorigenesis (Elmore, 2007). There are two main pathways of apoptosis. The first is the extrinsic known as death receptor pathway, and the second is the intrinsic known as mitochondrial pathway. Both pathways are interrelated and molecules on one pathway could affect 
the other. The pathways unite on the same terminal i.e. execution pathway which is initiated by caspases activation and subsequently caused by DNA fragmentation, degradation of proteins within the cell, the formation of apoptotic bodies, expression of ligands for immune system receptors and ultimately uptake by phagocytic cells (Elmore, 2007). Various anticancer agents and therapy heavily depend on apoptosis to kill breast cancer cells (Simstein et al., 2003).

Torbangun (Plectranthus amboinicus (Lour.) Spreng) is a medicinal plant that has been traditionally used in China, India, and Brazil to cure various illnesses (Brandao et al., 2013; Chiu et al., 2012; Gurgel et al., 2009; Kaliappan and Viswanathan, 2008). In Indonesia, the plant has been consumed for breast milk stimulant by Bataknese women for hundreds of years (Damanik, 2009). Bioactive compounds from the plant are reported to have anti-tumor activity against Sarcoma-180 and Ehrlich ascites carcinoma (Brandao et al., 2013; Gurgel et al., 2009), human hepatocellular carcinoma HEPG2 and breast cancer MCF-7 cell (El-hawary et al., 2012; Hasibuan, 2013; Thirugnanasampandan et al., 2015). The previous studies, however did not identify the compounds that responsible to the activity and the possible intracellular mechanism was also yet to be explored. Therefore the aim of this study was to identify the active compounds in the selected fractions of $P$ amboinicus plant extract which have an effect on the apoptosisrelated genes expression of breast cancer cell MCF-7.

\section{MATERIALS AND METHODS}

Origin and The Preparation of The Plant Fractions

Chloroform fraction of Plectranthus amboinicus (Lour.) Spreng used in this study was originated from our previous work (Yulianto et al., 2016). $P$ amboinicus plants were planted in Leuwikopo experimental garden of Bogor Agricultural University (Figure 1) and the specimen of the plant has been authenticated by The Research Center for Biology, Indonesian Institute of Science (LIPI Bogor-Indonesia). Briefly, the plant leaves were harvested, lyophylized, and extracted with ethanol $80 \%$ using combination of maceration and sonication. The ethanolic extract was then fractionated using manual liquid-liquid sequential solvent extraction based on the method by (Maser et al., 2015) resulting in 4 fractions including hexane, chloroform, ethyl acetate and water fraction. The chloroform fraction was selected because the fraction showed the highest activity on inhibiting the viability of MCF-7 (data not shown). In this study we used two different concentration, $1.6 \mu \mathrm{g} / \mathrm{ml}$ and $0.6 \mu \mathrm{g} / \mathrm{ml}$ where the first concentration came from the $\mathrm{IC}_{50}$ value (concentration to inhibit $50 \%$ of cell viability, based on our previous work) while the second concentration was equivalent to the $\mathrm{IC}_{25}$ value (concentration to inhibit 25\% of cell viability).

\section{MCF-7 Cell Culture}

Human breast cancer MCF-7(ATCC ${ }^{\circledR}$ HTB$22^{\mathrm{TM}}$ ) cell was kindly provided by The Laboratory of Microbiology and Immunology, Primate Research Center, Bogor Agricultural University. MCF-7 cells were grown in RPMI 1640 (SigmaAldrich) supplemented with $10 \%$ fetal bovine serum (Gibco), $50 \mathrm{IU} / \mathrm{ml}$ penicillin and $50 \mathrm{ng} / \mathrm{ml}$ streptomycin (Gibco) and incubated at $37^{\circ} \mathrm{C}$ in a humidified $5 \% \mathrm{CO}_{2}$ atmosphere (Yulianto et al., 2016).

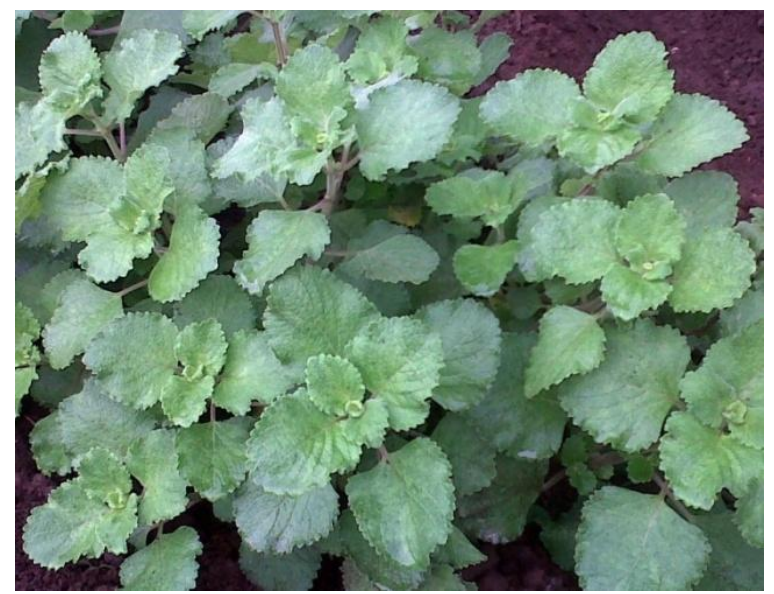

Figure 1.Torbangun plant (Plectranthus amboinicus (Lour.) Spreng)

\section{Cell morphology observation using Hoechst 33342 nuclear staining}

MCF-7 cells were seeded in 8 well chamber slide containing RPMI 1640 with the concentration of $5 \times 10^{3}$ cell/well and incubated for $24 \mathrm{~h}$ at $37^{\circ} \mathrm{C}$ in $5 \% \mathrm{CO}_{2}$. The media was replaced with fresh medium containing selected $P$ amboinicus fraction (Chloroform fraction at concentration of $1.6 \mu \mathrm{g} / \mathrm{ml}$ and $0.6 \mu \mathrm{g} / \mathrm{ml}$ ). After $48 \mathrm{~h}$ of incubation, the media were removed from the chamber and washed 3 times with PBS (Dulbecco's PBS, Gibco). The cells were fixated by the addition of $250 \mu$ l of $10 \%$ formaldehyde in each well and held for $1 \mathrm{~h}$. The formaldehyde was removed and washed with PBS 3 times. About $250 \mu \mathrm{l}$ of Hoechst 33342 solution (Invitrogen) was added to each well and incubated at $37^{\circ} \mathrm{C}$ for $1 \mathrm{~h}$. The Hoechst solution was removed and washed 3 times with PBS and dried at room 
temperature. Cell nuclear morphology was observed under fluorescence microscope (Nikon Optivat-2) and the cell pictures were taken by using Dino Eye software (AnMo, Taiwan).

\section{Apoptosis-related gene expression analysis using quantitative real-time PCR}

MCF-7 cells were seeded in 6 well plate containing RPMI 1640 with the concentration of 5 $\mathrm{x} 10^{5}$ cell/well and incubated for $24 \mathrm{~h}$ at $37^{\circ} \mathrm{C}$ under $5 \% \mathrm{CO}_{2}$. The media was replaced with fresh medium containing $P$ amboinicus chloroform fraction at concentration of $1.6 \mu \mathrm{g} / \mathrm{ml}$ and 0.6 $\mu \mathrm{g} / \mathrm{ml}$. After $48 \mathrm{~h}$ of incubation, the cells were harvested and stored below $-20^{\circ} \mathrm{C}$ until subsequent process. RNA was extracted from the cell pellets using RNeasy mini kit (Qiagen) with the procedure according to the manufacturer. The RNA concentration was determined using Nanodrop RNA measurement.

Quantitative real-time PCR were conducted using $100 \mathrm{ng} / \mu \mathrm{lRNA}$ samples and Master Mix in 20il reaction volume using KAPA SYBR® FAST Bio-Rad iCycler ${ }^{\mathrm{TM}}$ One-Step qRT-PCR Kit (KAPA Biosystems). Real-time PCR reactions were conducted in duplicate with the following running program: $42^{\circ} \mathrm{C}$ for $5 \mathrm{~min}$ (reverse transcription), followed by $95^{\circ} \mathrm{C}$ for $3 \mathrm{~min}$ (enzyme inactivation), and continued with 35 cycles of denaturation $\left(95^{\circ}\right.$ C for 3 seconds) and annealing/extension/data acquisition (for 30 seconds at the genes optimum annealing temperature, each gene used different optimum annealing temperature). Controls without RNA template were used as the control for all primers which were also done in duplicate. The genes observed including Bax, Bcl-2, p53, p21, Caspase 9, Caspase 7, and Caspase 1. Result analysis was calculated using delta-delta CT (Livak method) which normalized using ACTB gene (Livak and Schmittgen, 2001).

\section{Lc-Ms Analysis to Identify the Bioactive Compound}

Samples were subjected to LC-MS analysis. LC-MS system and the condition are similar to the study by (Maser et al., 2015). The identity of the compound was predicted based on fragmentation pattern of the mass spectra compared to literature.

\section{Statistical Analysis}

Data of gene expressions were analyzed with One way ANOVA (SPPS Version 21) followed by Duncan's Multiple Range Test.

\section{RESULTS AND DISCUSSION \\ Cell morphology}

Apoptosis can be identified by observing cell morphology since the programmed cell death is characterized by its distinct morphological characteristic (Elmore, 2007). Hoechst 33342 dye can bind to nuclear DNA so the entire nuclear material is stained to allow identification of apoptotic nuclei (Whiteside et al., 1998). The result of the cell morphology observation showed that treatment of the cell with the plant fraction at all concentration lead to cell shrinkage (Figure 2). In this phase, the cells are getting smaller in size, the cytoplasm is denser and the organelles are more tightly packed. The key feature of apoptosis i.e. chromatin condensation was observed hence confirm apoptosis in this study. During chromatin condensation, the electron-dense nuclear material aggregates peripherally beneath the nuclear membrane or can also break the membrane to form dense nuclei (Elmore, 2007). The observation of cell morphology using electron microscope in this study, however did not measure the degree of apoptosis. We confirm that the cell has undergone apoptosis qualitatively due to the treatment, but we could not compare the percentage of the apoptotic cell between the different concentrations quantitatively. Therefore it is suggested to use additional methods such as flow cytometry to achieve the quantitative data for future experiments.

\section{Apoptosis-related Genes Expression}

This study mainly focused on the intrinsic pathway of apoptosis which involved a nonreceptor mediated stimuli producing signals that act directly on target within the cell. The events are initiated in mitochondria where a bioactive compound can create stimulation to alter mitochondrial membrane permeability lead to the release of pro-apoptotic proteins such as cytochrome $c$ into the cytosol. The events are regulated by members of Bcl-2 family proteins including pro-apoptotic proteins such as Bax, Bak, Bad, Bcl-xs and Nip3; and anti-apoptotic proteins such as Bcl-2, Bcl-xl, Mcl-1 and Bfl-1/A1 (Simstein et al., 2003). The result of real time PCR showed that the mRNA expression of anti-apoptotic Bcl-2 gene was up-regulated as the effect of chloroform fraction (Figure 3). Higher concentration creates a higher level of mRNA expression. On the contrary, the pro-apoptotic gene Bax was not affected by the treatment. In line with our result, a study by (Burmistrova et al., 2013) reported that increased expression of protective mitochondrial protein Bcl-2 and Bcl-xl in human tumor cell lines did not prevent the cytotoxicity induced by abietane 

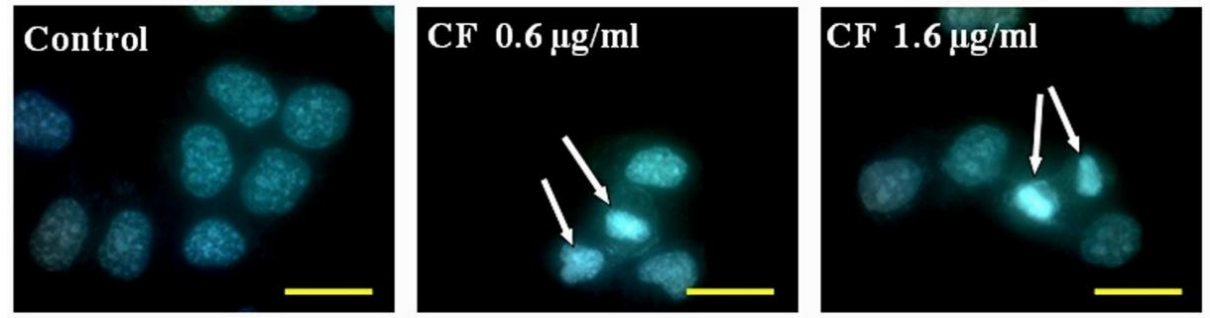

Figure 2 MCF-7 cells were treated with indicated concentration of Chloroform fraction for 48 hr. The nuclei were stained by using Hoechst 33342 and observed under fluorescence microscope. White arrows indicated the condensed nuclei in the cells. Yellow bar indicates the length sized $30 \mu \mathrm{m}$

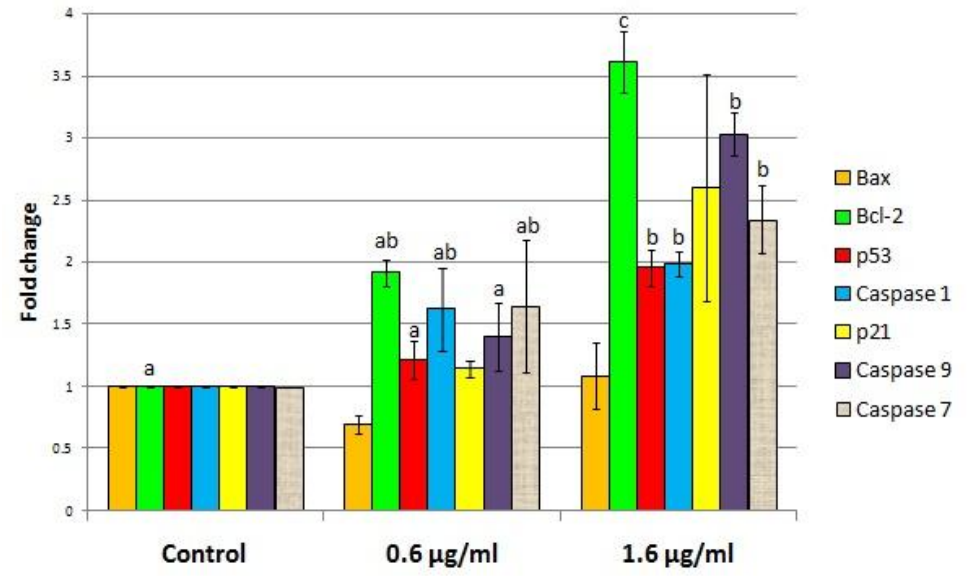

Figure 3 Expression of mRNA of apoptosis-related genes in fold change after treated with chloroform fraction with different concentration compared to control. Error bars are standard deviation from two replications. Different small letter above the bars represent significant difference $(\mathrm{P}<0.05)$.

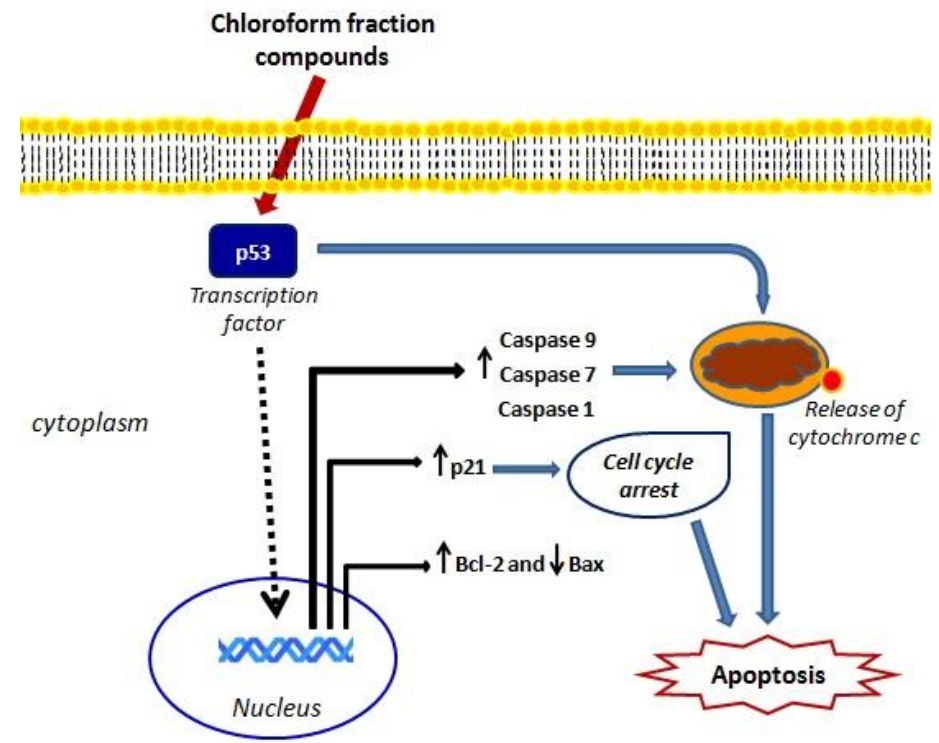

Figure 4 Proposed pathway of apoptosis induced by compounds in P. amboinicus chloroform fraction. Solid black bent arrows indicate transcription. Downstream of p53 induced by chloroform fraction compounds may used both transcription of pro-apoptotic genes and directly influence BAX protein in mitochondria which subsequently releases cytochrome c. 
diterpenoids being tested. Regarding the unaffected pro-apoptosis Bax gene expression, (Chipuk et al., 2003) explained that a tumor suppressor protein p53 may alter mitochondrial membrane permeability and hence induce apoptosis by direct stimulation of BAX protein in the mitochondria without transcription of any apoptosis-related genes.

Apart from being a tumor suppressor protein, p53 also acts as a transcription factor which responsible to activate expression of a number of target genes contributing to various biological effects such as apoptosis and cell cycle arrest (el-Deiry, 1998). The result showed that chloroform fraction significantly increased mRNA expression of p53 and p21 genes at higher concentrations (Figure 3). Molecule p21 (also known as p21 WAF1/Cip1) is a kinase-dependent inhibitor which functioned as a promoter of cell cycle arrest in response to various inductions (Abbas and Dutta, 2009; Weiss, 2003). Up regulation of p53 and p21 genes by the chloroform fraction indicated that the bioactive compound can induce apoptosis in MCF-7 cells through a pathway involving p53 and p21 molecules. The present results are in accordance with some previous studies. Protein p53 and p21 expression were up-regulated in the apoptosis induced by withaferin, a steroidal lactone occurring in Withania somnifera (Zhang et al., 2011). Expression of p53 protein is increased in the apoptosis induced by 17-B estradiol analogue (Visagie et al., 2015), Anthraquinone derivative increased p53 protein expression and p21 gene expression which subsequently affect the downstream genes such as PLK1 and FOXM1 and hence contributed to the $\mathrm{G} 2 / \mathrm{M}$ arrest of the cell and ultimately cause apoptosis (Yeap et al., 2015).

After the treatment of chloroform fraction, mRNA expression of initiator caspase (caspase 9) and executor caspase (caspase 7) were increased at both concentration of $1.6 \mu \mathrm{g} / \mathrm{ml}$ and 0.6 $\mu \mathrm{g} / \mathrm{mland}$ the degree of increments were dose dependent (Figure 3). The torbangun plant fraction treatment also activates caspase 1 , a member of inflammatory caspase. Caspase 1, formerly named as interleukin-1â converting enzyme (ICE) was reported to be the key player in Tumor necrosis factor alpha (TNF-á) and Fas ligand (FasL)-induced apoptosis (Chin et al., 1997). Apoptosis pathway involving transmembrane receptor such as TNF is considered as extrinsic pathway (Elmore, 2007). Activation of caspase 1 , however, may not be the result of a downstream signal from TNF-á and FasL since the ligand is very specific to immune cells derived antibody (Ashkenazi and Dixit, 1998). Instead, it might be due to crosslinking interaction between the molecules in the extrinsic pathway and the molecules within the intrinsic pathway such as p53 (Sprick and Walczak, 2004). The result of this study revealed that apoptosis induced by torbangunchloroform fraction utilized both intrinsic and extrinsic signaling pathway.

Based on above results, we proposed a pathway of apoptosis induced by bioactive compounds in chloroform fraction of torbangun plant extract (Figure 4). Compounds from chloroform fraction infiltrate the cell membrane to target p53. The activated p53 may subsequently induce transcription of pro-apoptotic genes such as caspase 9 and caspase 7 as well as p21. In addition, p53 may also directly influence the mitochondrial membrane permeability to release pro-apoptotic proteins and hence resulting apoptosis. This may be one of the reasons why increased expression of anti-apoptosis Bcl-2 gene and decreased expression of pro-apoptotic Bax gene could not prevent the cell from apoptosis.

\section{Bioactive Compounds of Plectranthus amboinicus Fractions}

The chemical profiles of the chloroform fraction used in this study were analyzed by injecting the samples into the LC-MS system using gradient elution. The chromatogram of the chloroform fraction is presented in Figure 5. The polarity of the mobile phase gradually changed from polar to non polar and achieved its maximum at the $6^{\text {th }}$ minutes and subsequently returned to its initial polarity. Therefore, the peaks generated within the retention time of 1-6 minutes are considered as the chemical profile of the samples. The compounds started to be eluted after $3.5 \mathrm{~min}$ and tend to be grouped towards the later period of retention time, hence confirm that the compounds are non polar (Figure 5).

Predicted compounds of the fraction listed in Table 1 weredetermined based on mass spectral data analysis compared to the literature. Some compounds are presented in chloroform fraction such as forskolin J, betulin, coleon U quinone, horminone, lanugone $B$ and 7á-acetoxy-6âhydroxyroyleanone. Most of the predicted compounds have been previously recorded from genus Plectranthus (Abdel-Mogib et al., 2002; Lukhoba et al., 2006). Forskolin is a labdane diterpenoid which is found in $P$. Barbatus (Lukhoba et al., 2006). Forskolin is well known as an activator of cAMP-dependent protein kinase A signaling pathway which could have anti cancer properties (Huang et al., 2005). The earlier study, however, reported that forskolin weakly inhibited MCF-7 cell proliferation (Melck et al., 1999). 


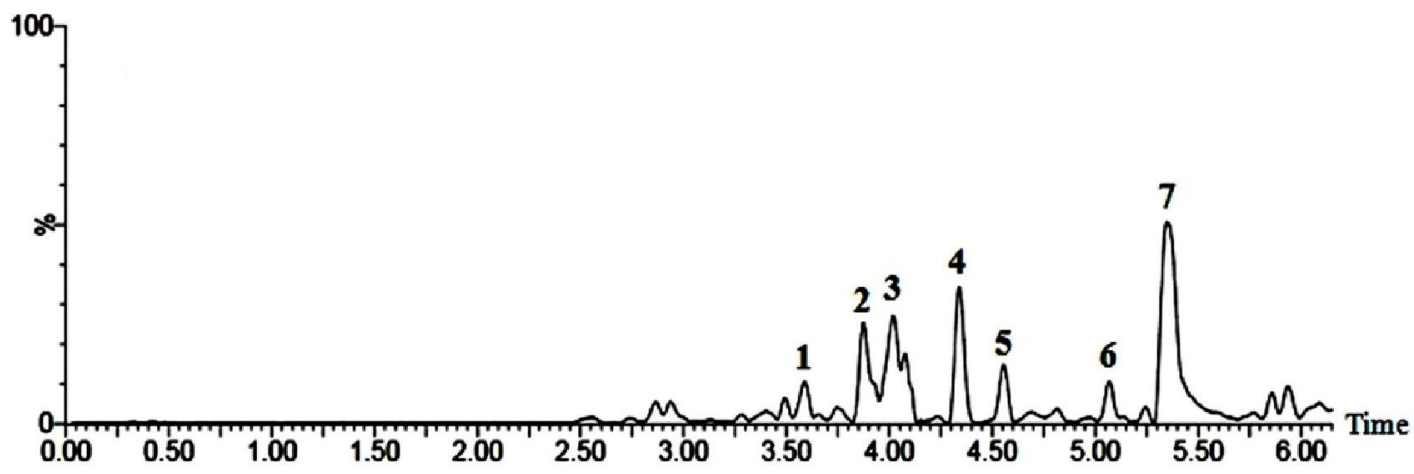

Figure 5 Chromatogram of chloroform fraction generated by LC-MS. Number above the peaks are correspond to the number in table I

Table I. Prediction of compounds in chloroform fraction based on the mass spectra data

\begin{tabular}{|c|c|c|c|c|c|c|}
\hline \multirow{2}{*}{ No } & \multirow{2}{*}{$\begin{array}{l}\text { Retention } \\
\text { Time (min) }\end{array}$} & \multicolumn{2}{|c|}{ Mass spectra data } & \multirow{2}{*}{$\begin{array}{l}\text { Molecular } \\
\text { formula }\end{array}$} & \multirow{2}{*}{ Name of compound } & \multirow{2}{*}{ Reference } \\
\hline & & Ion & $\mathbf{m} / \mathbf{z}$ & & & \\
\hline 1 & 3.599 & {$[\mathrm{M}+\mathrm{H}]^{+}$} & 453.3020 & $\mathrm{C}_{24} \mathrm{H}_{36} \mathrm{O}_{8}$ & Forskolin J & (Lukhoba et al., 2006) \\
\hline 2 & 3.875 & {$[\mathrm{M}+\mathrm{H}]^{+}$} & 443.2186 & $\mathrm{C}_{30} \mathrm{H}_{50} \mathrm{O}_{2}$ & Betulin & $\begin{array}{c}\text { (Abdel-Mogib et al., } \\
\text { 2002) }\end{array}$ \\
\hline 3 & 4.017 & {$[\mathrm{M}+\mathrm{H}]^{+}$} & 305.3577 & $\mathrm{C}_{20} \mathrm{H}_{32} \mathrm{O}_{2}$ & $\begin{array}{c}\text { 7a,18-dihydroxy- } \\
\text { isopimara-8(14),15-diene }\end{array}$ & (Rasikari, 2007) \\
\hline 4 & 4.336 & {$[\mathrm{M}+\mathrm{H}]^{+}$} & 333.3946 & $\mathrm{C}_{20} \mathrm{H}_{28} \mathrm{O}_{4}$ & Horminone & $\begin{array}{l}\text { (Abdel-Mogib et al., } \\
\text { 2002) }\end{array}$ \\
\hline 5 & 4.558 & {$[\mathrm{M}+\mathrm{H}]^{+}$} & 329.1722 & $\mathrm{C}_{20} \mathrm{H}_{24} \mathrm{O}_{4}$ & Lanugone B & $\begin{array}{l}\text { (Abdel-Mogib et al., } \\
\text { 2002) }\end{array}$ \\
\hline 6 & 5.073 & {$[\mathrm{M}+\mathrm{H}]^{+}$} & 345.2380 & $\mathrm{C}_{20} \mathrm{H}_{24} \mathrm{O}_{5}$ & Coleon U quinone & $\begin{array}{l}\text { (Abdel-Mogib et al., } \\
\text { 2002) }\end{array}$ \\
\hline 7 & 5.370 & {$[\mathrm{M}+\mathrm{Na}]^{+}$} & 413.1931 & $\mathrm{C}_{22} \mathrm{H}_{30} \mathrm{O}_{6}$ & $\begin{array}{c}7 \alpha \text {-acetoxy- } 6 \beta- \\
\text { hydroxyroyleanone }\end{array}$ & (Rasikari, 2007) \\
\hline
\end{tabular}

Coleon $\mathrm{U}$ quinone has been found in P. forsteri 'Marginatus' Benth and reported to showed antifeedant and antibacterial activity (Wellsow et al., 2006). A diterpene horminone which isolated from the Chilean Lamiaceae Schacele chamaedryoides (Balbis) Briq was reported to have gastroprotective effect in mice model and cytotoxicity against gastric adenocarcinoma cells in vitro (Areche et al., 2009). Lanugone B is a royleanone diterpenoid found in $P$. lanuginosus also has been isolated from $P$. barbatus (AbdelMogib et al., 2002; Lukhoba et al., 2006). Betulin has shown anti cancer activity against various cancer cell lines such as neuroblastoma, breast, lung, colon carcinoma with the mode of action through altering tumour cell morphology, lowering the cell motility and inducing apoptotic cell death (Rzeski et al., 2009).

The most principle compound in chloroform fraction is 7á-acetoxy-6â- hydroxyroyleanone based on the peak size in the chromatogram. The abietane diterpene 7áacetoxy-6â-hydroxyroyleanone has been previously isolated from $P$. grandidentatus Gurke and reported to possess strong anti-proliferative activity against various human cancer cell lines including MCF-7, NCl-H460, SF-268, TK-10, and UACC-62 (Burmistrova et al., 2013; Marques et al., 2002). By knowing the bioactive compounds of the fraction which responsible for the apoptosis inducing activity, may give basic information prior to the development of this herbal plant as a potential candidate for therapy of cancer.

\section{CONCLUSIONS}

The morphology of apoptotic cells, such as cell shrinkage and chromatin condensation was clearly observed. Bioactive compounds in chloroform fraction induce apoptosis by the role of p53 as transcription factor and tumor suppressor 
protein. Increased expression of anti-apoptotic gene Bcl-2 could not prevent the cells from apoptosis. The expression of pro-apoptotic genes was increased at concentration-dependent manner. Most of the compounds in the chloroform fraction are identified as diterpenoids which may contribute to the apoptosis inducing the activity of the fraction.

\section{ACKNOWLEDGEMENT}

The authors wish to express special gratitude to Ms. Silmi Mariya and Dr. Uus Saepuloh for valuable help during cancer cell laboratory works and Real-Time PCR analysis.

\section{REFERENCES}

Abbas, T., Dutta, A., 2009. P21 in Cancer: Intricate Networks and Multiple Activities. Nat. Rev. Cancer 9, 400-414. doi:10.1038/nrc2657

Abdel-Mogib, M., Albar, H.A., Batterjee, S.M., 2002. Chemistry of the genus Plectranthus. Molecules. doi:10.3390/70200271

Areche, C., Schmeda-Hirschmann, G., Theoduloz, C., Rodríguez, J. a, 2009. Gastroprotective effect and cytotoxicity of abietane diterpenes from the Chilean Lamiaceae Sphacele chamaedryoides (Balbis) Briq. J. Pharm. Pharmacol. 61, 1689-1697. doi:10.1211/jpp/61.12.0015

Ashkenazi, A., Dixit, V.M., 1998. Death receptors: signaling and modulation. Science 281, 1305-1308. doi:10.1126/science.281.5381.1305

Brandao, E.M., Brandão, P.H.D.M., Souza, I.A., Paiva, G.S., Carvalho, M. de C., Lacerda, C.M., 2013. Antineoplasic Effect of Aqueous Extract of Plectranthus Amboinicus in Ehrlich Ascites Carcinoma. J. Cancer 4, 573-576. doi:10.7150/jca.6730

Burmistrova, O., Simões, M.F., Rijo, P., Quintana, J., Bermejo, J., Estévez, F., 2013. Antiproliferative activity of abietane diterpenoids against human tumor cells. J. Nat. Prod. 76, 1413-1423. doi:10.1021/np400172k

Chin, Y.E., Kitagawa, M., Kuida, K., Flavell, R.A., Fu, X.Y., 1997. Activation of the STAT signaling pathway can cause expression of caspase 1 and apoptosis. Mol. Cell. Biol. 17, 5328-37.

Chipuk, J.E., Maurer, U., Green, D.R., Schuler, M., 2003. Pharmacologic activation of p53 elicits Bax-dependent apoptosis in the absence of transcription. Cancer Cell 4, 371-381. doi:10.1016/S1535-6108(03)00272-1

Chiu, Y.J., Huang, T.H., Chiu, C.S., Lu, T.C., Chen, Y.W., Peng, W.H., Chen, C.Y., 2012. Analgesic and antiinflammatory activities of the aqueous extract from Plectranthus amboinicus (Lour.) Spreng. both in vitro and in vivo. Evidence-based Complement. Altern. Med. 2012. doi:10.1155/2012/508137

Damanik, R., 2009. Torbangun (Coleus amboinicus Lour): a Bataknese traditional cuisine perceived as lactagogue by Bataknese lactating women in Simalungun, North Sumatera, Indonesia. J. Hum. Lact. 25, 64-72. doi:10.1177/0890334408326086

el-Deiry, W.S., 1998. Regulation of p53 downstream genes. Semin. Cancer Biol. 8, 345-57. doi:10.1006/scbi.1998.0097

El-hawary, S.S., El-sofany, R.H., Abdel-Monem, A.R., Ashour, R.S., Sleem, A. a, 2012. Polyphenolics content and biological activity of Plectranthus amboinicus (Lour.) spreng growing in Egypt (Lamiaceae). Pharmacogn. J. 4, 45-54. doi:http://dx.doi.org/10.5530/pj.2012.32.9

Elmore, S., 2007. Apoptosis: a review of programmed cell death. Toxicol. Pathol. 35, 495-516. doi:10.1080/01926230701320337

Gurgel, A.P.A.D., da Silva, J.G., Grangeiro, A.R.S., Oliveira, D.C., Lima, C.M.P., da Silva, A.C.P., Oliveira, R.A.G., Souza, I.A., 2009. In vivo study of the anti-inflammatory and antitumor activities of leaves from Plectranthus amboinicus (Lour.) Spreng (Lamiaceae). J. Ethnopharmacol. 125, 361363. doi:10.1016/j.jep.2009.07.006

Hasibuan, P.A.Z., 2013. Antioxidant and Cytotoxic Activities of Plectranthus amboinicus (Lour.) Spreng. Extracts. Int. J. Pharm. Teach. Pract. 4, 755-758.

Huang, W.C., Xie, Z., Konaka, H., Sodek, J., Zhau, H.E., Chung, L.W.K., 2005. Human osteocalcin and bone sialoprotein mediating osteomimicry of prostate cancer cells: role of cAMP-dependent protein kinase A signaling pathway. Cancer Res 65, 2303-2313.

Kaliappan, N., Viswanathan, P., 2008. Pharmacognostical studies on the leaves of Plectranthus amboinicus (Lour) Spreng. Int. J. Green Pharm. doi:http://dx.doi.org/10.4103/09738258.42740

Livak, K.J., Schmittgen, T.D., 2001. Analysis of relative gene expression data using real-time quantitative PCR and the 2(-Delta Delta C(T)) Method. Methods 25, 402-8. doi:10.1006/meth.2001.1262

Lukhoba, C.W., Simmonds, M.S.J., Paton, A.J., 2006. Plectranthus: A review of ethnobotanical uses. J. Ethnopharmacol. doi:10.1016/j.jep.2005.09.011 
Marques, C.G., Pedro, M., Simões, M.F.A., Nascimento, M.S.J., Pinto, M.M.M., Rodriguez, B., 2002. Effect of abietane diterpenes from Plectranthus grandidentatus on the growth of human cancer cell lines. Planta Med. 68, 839-840. doi:10.1055/s-2002-34407

Maser, W.H., Yuliana, N.D., Andarwulan, N., 2015. Rapid Identification of Antibacterial Compounds from Turkey Berry by HPLCBased Metabolomics. J. Liq. Chromatogr. Relat. Technol. 38, 37-41. doi:10.1080/10826076.2015.1032419

Melck, D., Rueda, D., Galve-Roperh, I., De Petrocellis, L., Guzmán, M., Di Marzo, V., 1999. Involvement of the cAMP/protein kinase A pathway and of mitogen-activated protein kinase in the anti-proliferative effects of anandamide in human breast cancer cells. FEBS Lett. 463, 235-240. doi:10.1016/S0014-5793(99)01639-7

Rasikari, H., 2007. Phytochemistry and arthropod bioactivity of Australian Lamiaceae. Southern Cross University.

Rzeski, W., Stepulak, A., Szymañski, M., Juszczak, M., Grabarska, A., Sifringer, M., Kaczor, J., Kandefer-Szerszeñ, M., 2009. Betulin Elicits Anti-Cancer Effects in Tumour Primary Cultures and Cell Lines in Vitro. Basic Clin. Pharmacol. Toxicol. 105, 425-432. doi:10.1111/j.1742-7843.2009.00471.x

Simstein, R., Burow, M., Parker, A., Weldon, C., Beckman, B., 2003. Apoptosis, chemoresistance, and breast cancer: insights from the MCF-7 cell model system. Exp. Biol. Med. (Maywood). 228, 995-1003. doi:15353702/03/2289-0995

Sprick, M.R., Walczak, H., 2004. The interplay between the Bcl-2 family and death receptormediated apoptosis. Biochim. Biophys. Acta Mol. Cell Res. doi:10.1016/j.bbamcr.2003.11.002

Thirugnanasampandan, R., Ramyaa, G., Gogulramnath, M., Jayakumar, R., Kanthimathi, M.S., 2015. Evaluation of cytotoxic, DNA protecting and LPS induced MMP-9 down regulation activities of Plectranthus amboinicus (Lour) Spreng. essential oil. Pharmacogn. J. 7, 32-36. doi:10.5530/pj.2015.7.3

Visagie, M.H., Birkholtz, L.-M., Joubert, A.M., 2015. A 2-methoxyestradiol bis-sulphamoylated derivative induces apoptosis in breast cell lines. Cell Biosci. 5, 1-15. doi:10.1186/s13578-015-0010-5

Weiss, R.H., 2003. p21Waf1/Cip1 as a therapeutic target in breast and other cancers. Cancer Cell. doi:10.1016/S1535-6108(03)00308-8

Wellsow, J., Grayer, R.J., Veitch, N.C., Kokubun, T., Lelli, R., Kite, G.C., Simmonds, M.S.J., 2006. Insect-antifeedant and antibacterial activity of diterpenoids from species of Plectranthus. Phytochemistry 67, 1818-1825. doi:10.1016/j.phytochem.2006.02.018

Whiteside, G., Cougnon, N., Hunt, S.P., Munglani, R., 1998. An improved method for detection of apoptosis in tissue sections and cell culture, using the TUNEL technique combined with Hoechst stain. Brain Res. Protoc. 2, 160-164. doi:10.1016/S1385-299X(97)00032-9

Yeap, S., Akhtar, M.N., Lim, K.L., Abu, N., Ho, W.Y., Zareen, S., Roohani, K., Ky, H., Tan, S.W., Lajis, N., Alitheen, N.B., 2015. Synthesis of an anthraquinone derivative (DHAQC) and its effect on induction of $\mathrm{G} 2 / \mathrm{M}$ arrest and apoptosis in breast cancer MCF-7 cell line. Drug Des. Devel. Ther. 9, 983-992. doi:10.2147/DDDT.S65468

Yulianto, W., Andarwulan, N. Giriwono, P.E., Pamungkas, J., 2016. HPLC-Based Metabolomics to Identify Cytotoxic Compounds from Plectranthus amboinicus (Lour.) Spreng against Human Breast Cancer MCF-7Cells. Journal of Chromatography $B$. 1039: 28-34. doi:10.1016 /j.jchromb.2016.10.024

Zhang, X., Mukerji, R., Samadi, A.K., Cohen, M.S., 2011. Down-regulation of estrogen receptor-alpha and rearranged during transfection tyrosine kinase is associated with withaferin a-induced apoptosis in MCF-7 breast cancer cells. BMC Complement. Altern. Med. 11, 84. doi:10.1186/1472-6882-11-84. 